\title{
BLOOD SERUM FREE AMINO ACIDS PATTERN IN NEWBORN CALVES ON COLOSTRAL DIET AND ORALLY TREATED WITH ZEOLITE
}

\author{
GVOZDIĆ D*, ALEKSIĆ JELENA*, FRATRIĆ NATALIJA*, JAKIĆ-DIMIĆ DOBRILA**, STOJIĆ V*, \\ PAVLOVIĆ $V^{*}$, PAVLOVIĆ $M^{*}$ and VAKANJAC SLOBODANKA* \\ *University of Belgrade, Faculty of Veterinary Medicine, Serbia \\ **Scientific Veterinary Institute of Serbia, Serbia
}

(Received 2nd February 2010)

Oral zeolite treatement effects on the blood serum free amino acid pattern in newborn calves was investigated. The total number of 30 newborn Holstein calves of both sexes, weighting $35 \pm 3 \mathrm{~kg}$ (mean $\pm S D$ ), were immediately after parturition separated from their dams and placed in individual pens. Calves were divided in two experimental groups, 15 calves each. All calves were bottle-fed twice/ day (1.5 L/meal) during the first 48 hours after delivery, in 12 hour intervals, with their mother's first (during 24 hours postpartum) or second colostrum (at 24-48 hours postpartum), starting two hours after delivery. Zeolite suspension (20 mL, 25\% suspension in distilled water) was added to every meal for treated calves.

Colostrum samples were collected from six cows at $0-12 \mathrm{~h}$ and $24 \mathrm{~h}$ after delivery. Total and colostral whey protein concentrations were determined using the colorimetric method. Blood samples were taken from the jugular vein of calves at 6, 16, 30 and 40 hours after birth. After spontaneous coagulation at room temperature blood serum was separated and stored at $-20^{\circ} \mathrm{C}$ until analyzed. Total protein concentration was determined by the colorimetric method. Blood serum immunoglobulin $\mathrm{G}$ (IgG) concentrations were determined using single radial immunodiffusion (sRID) plates. Pooled blood serum free amino acids (aspartic acid - Asp, glutamic acid - Glu, serine - Ser, histidine - His, glycine - Gly, threonine - Thr, alanine - Ala, proline - Pro, tyrosine - Tyr, arginine - Arg, valine - Val, methionine - Met, Leucine Leu, Isoleucine - Ile, phenylalanine - Phe) were identified and quantified using high-performance liquid chromatography (HPLC, GBC Australia).

Total and colostral whey protein concentrations were significantly higher in the first colostrum and decreased between 50-75\% at 24-48 hours later on. Mean blood serum IgG concentration was significantly increased at 6 and 16 hours in the treated calves $(26 \pm 7: 20 \pm 5$ and $55 \pm 15: 42 \pm 13 \mathrm{~g} / \mathrm{L}, p<0.05)$. Blood serum free amino acids $(A A)$ first were separated at nonessential and essential AA (NEAA and EAA, respectively), both being increased at all time intervals after birth in treated calves. However, when the pooled blood serum free $A A$ were 
clustered according to polarity and electrical charge and presented as relative values (\% of the control group values) at the $6 h$ there was a massive increase of polar positive (Arg, His), polar neutral (Ser, Thr, Tyr) and nonpolar neutral free AA (except Met). The minimal effect of oral zeolite treatment was on the negative polar blood serum free $A A$ concentration (Asp and Glu).

Key words: free ammino acids, zeolite, newborn calves, blood serum

\section{INTRODUCTION}

Newborn calves colostral diet has a high protein concentration, often dominated by immunoglobulins (Ig) (Butler, 1974). Colostral Ig concentration is very high (up to $100 \mathrm{~g} / \mathrm{L}$ ), and intact $\mathrm{lg}$ molecules are readily resorbed from the intestine of newborn animals (Stott et al., 1979a, 1979b, 1979c, 1983; Cabello et al., 1980; Kruse, 1983). Therefore, colostral Ig absorbtion may be crucial in providing temporary passive immunity to neonates. The absorbtion of intact colostral proteins is favored by several factors: 1) low proteolitic activity in the gastrointestinal tract (Gl) of newborn animals (Guilloteau et al., 1983), 2) trypsin inhibitors present in the colostrum (Jensen, 1978; Pallavicini et al., 1984). However, protein metabolism and nitrogen turnover are extreemly intensive during early post-natal period (Patureau Mirand et al., 1985, 1990), and nutrient requirements for amino acids are relatively high. Colostral proteins therefore seem to have two separate and completely opposite functions: 1) to establish passive immune protection, which is supported by limited digestion, and 2) to provide large amounts of amino acids, which requires complete protein digestion. Blood serum Ig level is significantly increased in newborn calves and piglets on colostral diet and orally treated with zeolite (Stojić et al., 1995; 1998). However, in vitro research showed no significant influence of zeolite on some free amino acid adsorption (Tomašević-Čanović et al., 1996). The aim of this work was to investigate blood serum free amino acids pattern in newborn calves on colostral diet and orally treated with zeolite.

\section{MATERIALS AND METHODS}

Mineral adsorbent. A sample of natural zeolitic rich tuff from the Zlatokop deposit (Vranje, southern Serbia) was used in this study. The mineralogical composition of the natural zeolitic tuff was primarily clinoptilolite/heulandite (HEU) - minimum $85 \%$, with trace amounts of feldspar and quartz, as determined by Xray power diffraction (XRPD) analysis. HEU group zeolites have the same framework topology, but clinoptilolite and heulandite are differentiated on their chemical composition, thermal stability, and ${ }^{1} \mathrm{H}$ NMR spectra (Mumpton, 1998; Ward and McKague, 1994). Thermal stability study (Mihajlović-Radosavljević et 
al., 2003) and ${ }^{1} \mathrm{H}$ NMR analysis (Daković et al., 2007), showed that natural zeolitic tuff from Zlatokop deposit (Serbia) is rich in mineral clinoptilolite.

Chemical composition of the clinoptilolite rich zeolitic tuff (clinoptilolite), determined by atomic absorption spectroscopy, is given in Table 1.

Table 1. Chemical composition of the mineral adsorbent (\%)

\begin{tabular}{|l|c|c|c|c|c|c|c|c|c|}
\hline Component & $\mathrm{SiO}_{2}$ & $\mathrm{Al}_{2} \mathrm{O}_{3}$ & $\mathrm{Fe}_{2} \mathrm{O}_{3}$ & $\mathrm{TiO}_{2}$ & $\mathrm{CaO}$ & $\mathrm{MgO}$ & $\mathrm{Na}_{2} \mathrm{O}$ & $\mathrm{K}_{2} \mathrm{O}$ & L.I. \\
\hline Content, \% & 64.21 & 11.48 & 0.88 & 0.25 & 4.55 & 1.45 & 1.71 & 1.29 & 14.00 \\
\hline
\end{tabular}

The predominant cation associated with clinoptilolite was calcium and the minimum cation exchange capacity (CEC) was $146 \mathrm{mmolM}^{+} / 100 \mathrm{~g}$ (Table 2) measured by the ammonium chloride method.

Table 2. CEC and exchanging cations of the mineral adsorbent

\begin{tabular}{|l|c|c|c|c|c|}
\hline Exchangeable cation & $\mathrm{Ca}^{++}$ & $\mathrm{Mg}^{++}$ & $\mathrm{Na}^{++}$ & $\mathrm{K}^{+}$ & $\Sigma$ \\
\hline $\mathrm{CEC}$ mmolM $+100 \mathrm{~g}$ & 95 & 13 & 22 & 16 & 146 \\
\hline
\end{tabular}

Thermogravimetric analysis of the used clinoptilolite (plot is not shown) showed continuous weight loss during heating up to $800^{\circ} \mathrm{C}$, due to the loss of hygroscopic water and loss of water residing in the channels and cavities of the zeolite framework; the total water content was $13.80 \%$. Thermal analysis was performed on a Netzsch STA 409 EP. The sample was heated $\left(20-800^{\circ} \mathrm{C}\right)$ in an air atmosphere, with a heating rate of $10^{\circ} \mathrm{C} / \mathrm{min}$.

A fine powder, $<10 \mu \mathrm{m}$ fraction of clinoptilolite, was used in the experiments. The particle size of the material was determined on a Coulter Counter. The average particle size was $4.5 \mu \mathrm{m}(99.9 \%$ of the particles $<10 \mu \mathrm{m}$ and $90.0 \%$ $<7 \mu \mathrm{m})$. For the experiments, a $25 \%$ suspension of clinoptilolite in distilled water was prepared.

Animals and treatments. The experiment was carried out on a total number of 30 newborn Holstein calves, both sexes, $35 \pm 3 \mathrm{~kg}$ (mean \pm SD) body weight, which were immediately after parturition separated from their dams and placed in individual pens. Calves were divided in two experimental groups, 15 calves each. All calves were bottle-fed twice/day during the first 48 hours after delivery, in 12 hour intervals, with their mother's first or second colostrum $(1.5 \mathrm{~L} / \mathrm{meal})$, starting two hours after delivery. Zeolite suspension $(20 \mathrm{~mL}, 25 \%$ suspension in distilled water) was added to every meal for the treated calves. The experimental protocol for control and treated calves is presented in Table 3.

Colostral total protein and Ig samples. Colostrum samples were collected from six cows at $0-12 \mathrm{~h}$ and $24 \mathrm{~h}$ after delivery. Total and colostral whey protein concentrations were determined using the colorimetric method. 
Table 3. The experimental protocol for control and treated calves

\begin{tabular}{|l|c|c|c|}
\hline & Zeolite & $\begin{array}{c}\text { First colostrum } \\
(0-12 \mathrm{~h})\end{array}$ & $\begin{array}{c}\text { Second colostrum } \\
(24-48 \mathrm{~h})\end{array}$ \\
\hline \hline Control (Con) & - & First two meals & Second two meals \\
\hline Treated (Zeo) & $\star 20 \mathrm{~mL}$ & First two meals & Second two meals \\
\hline
\end{tabular}

Legend: *25\% zeolite suspension in distilled water

Blood serum samples. Blood samples were taken from the jugular vein of calves at 6, 16, 30 and 40 hours after birth. After spontaneous coagulation at room temperature blood serum was separated and stored at $-20^{\circ} \mathrm{C}$ until analyzed.

Blood serum total protein, $\mathrm{Ig}$ and free amino acids determination. Total protein concentration was determined by the colorimetric method. Blood serum IgG concentrations were determined using single radial immunodiffusion (sRID) plates containing monospecific antisera in buffered agarose. Reference standards were pipetted $(5 \mu \mathrm{L})$ into the first four wells of each agarose plate, and serum samples were pipetted $(5 \mu \mathrm{L})$ into the remaining wells of each agarose plate. The IgG serum samples were diluted 1:30 with saline $(2.9 \mathrm{~mL}$ saline and $0.1 \mathrm{~mL}$ sera) before they were added to sRID plates. The plates were left undisturbed at room temperature for 24 to $48 \mathrm{~h}$, and the ring diameters were read using a finescale comparator RID-meter (millimeters). The diameters were plotted on a scale with reference standards to obtain the serum and colostral $\mathrm{lgG}(\mathrm{g} / \mathrm{L})$ concentrations. Each sample was set in duplicate. Duplicate analyses of samples gave a repeatability within $5 \%$.

Blood serum free amino acids (aspartic acid - Asp, glutamic acid - Glu, serine - Ser, histidine - His, glycine - Gly, threonine - Thr, alanine - Ala, proline Pro, tyrosine - Tyr, arginine - Arg, valine - Val, methionine - Met, Leucine - Leu, Isoleucine - Ile, phenylalanine - Phe) were identified and quantified using highperformance liquid chromatography (HPLC, GBC Australia). Amino acids were treated with fluorenylmethylchlor-formiate (FMOC-CI). Amino acids derivates were separated at ODS, Hypersil column (150 x $4.6 \mathrm{~mm}$ ID) with mobile phases gradient $30 \mathrm{mM}$ amonium phosphate $(\mathrm{pH}=6.5)$ in $15 \%$ methanol, $90 \%$ acetonitrile. Amino acids FMOC derivates were detected using fluorescent detector LC 1250 GBC (extinction I $=2790 \mathrm{~nm}$, emisson I = $316 \mathrm{~nm}$ ). Amino acids were qantified using internal standard methodology (L-hydroxy proline).

Amino acids (AA) were grouped as: 1) nonessential and essential $A A$ (NEAA and EAA, respectively) and 2) polar positive AA (Arg and His); polar negative AA (Asp and Glu); polar neutral AA (Ser, Thr, Tyr); nonpolar neutral AA (Ala, Gly, lle, Leu, Met, Phe, Pro, Val).

\section{RESULTS}

Total and colostral whey protein concentrations in the first and second colostrum are presented in Table 4. 
Acta Veterinaria (Beograd), Vol. 60, No. 2-3, 411-423, 2010.

Table 4. Total and colostral whey protein concentrations $(\mathrm{X} \pm \mathrm{SD} \mathrm{g} / \mathrm{L})$

\begin{tabular}{|l|c|c|}
\hline \multirow{2}{*}{ Sample $(\mathrm{n}=6)$} & \multicolumn{2}{|c|}{ Time after delivery } \\
\cline { 2 - 3 } & $0-12 \mathrm{~h}$ & $24-48 \mathrm{~h}$ \\
\hline \hline Colostrum & $139 \pm 14^{\star *}$ & $57 \pm 8$ \\
\hline Colostral whey & $82 \pm 11^{\star *}$ & $22 \pm 1$ \\
\hline
\end{tabular}

Legend: ${ }^{* *}-p<0.01$

Total and colostral whey protein concentrations were significantly higher $(139 \pm 14: 57 \pm 8$ and $82 \pm 11: 22 \pm 1 \mathrm{~g} / \mathrm{L}, \mathrm{p}<0.01)$ in the first colostrum that has been sampled during 12 hours after delivery. After 24-48 hours total colostral protein and colostral whey protein concentration decreased between $50-75 \%$.

Blood serum total protein, albumin and Ig concentrations in the control and calves orally treated with zeolite are presented in Figures 1-3.

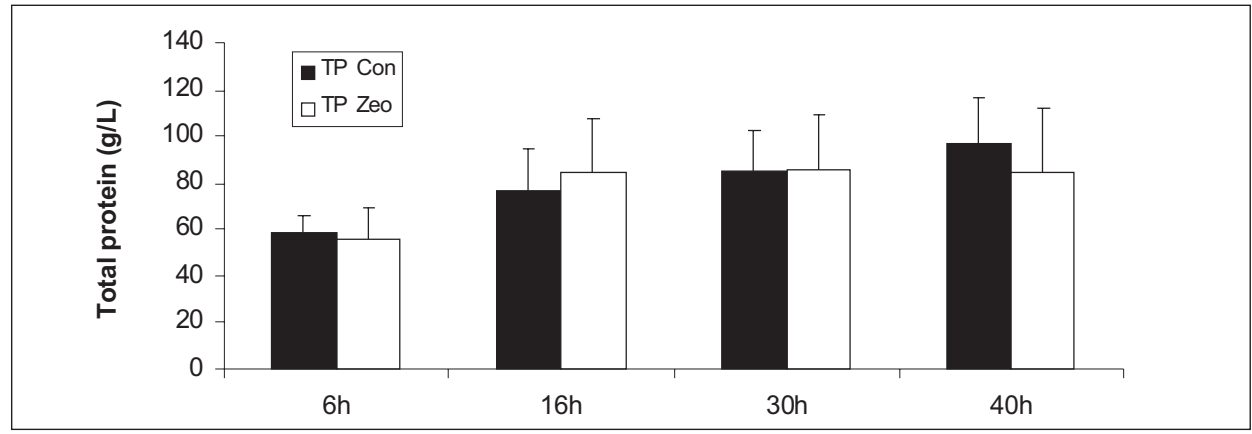

Figure 1. Blood serum total protein concentration in the control and calves orally treated with zeolite $(X \pm S D, g / L)$

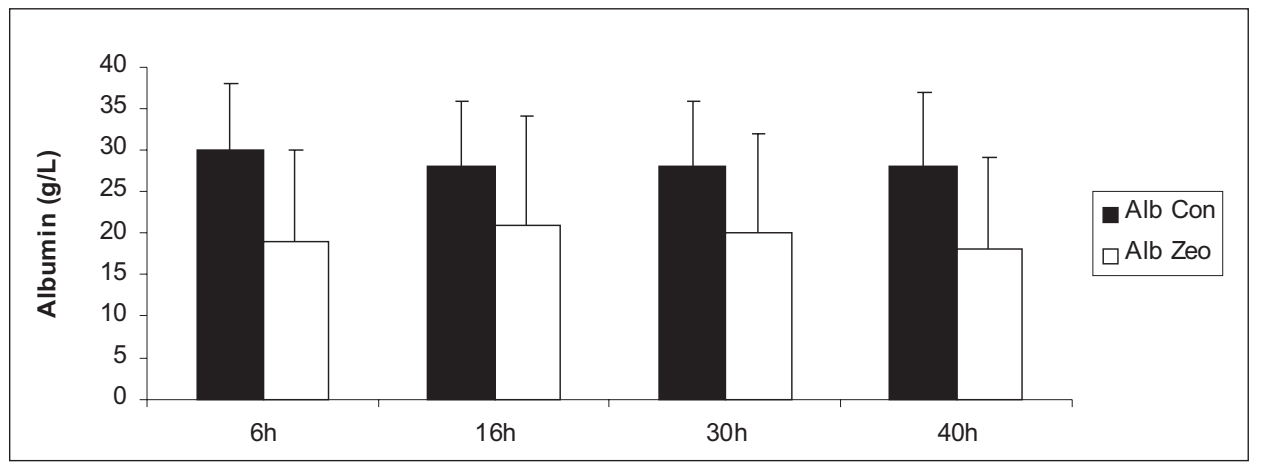

Figure 2. Blood serum albumin concentration in the control and calves orally treated with zeolite $(X \pm S D, g / L)$ 


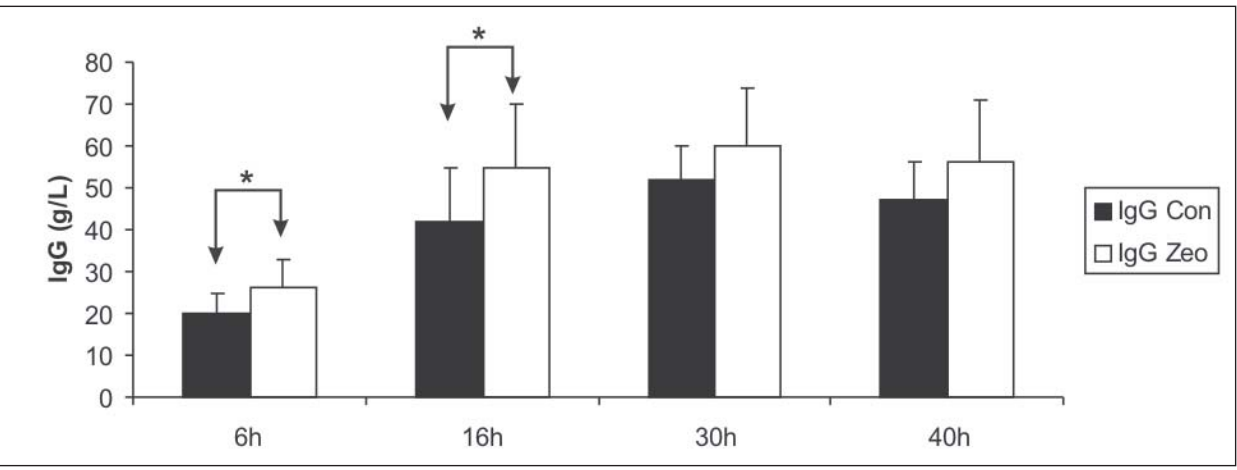

Figure 3. Blood serum IgG concentration in the control and calves orally treated with zeolite $(\mathrm{X} \pm \mathrm{SD}, \mathrm{g} / \mathrm{L})$

There was no statistically significant differences in total blood serum protein concentration between treated and control group of calves (Figure 1). Blood serum albumin concentration was continously lower in treated calves (Figure 2), but there were no statistically significant differences between control and treated calves. However, blood serum IgG concentration was significantly increased at 6 and 16 hours in treated calves (Figure 3, 26 $\pm 7: 20 \pm 5$ and 55 $\pm 15: 42 \pm 13 \mathrm{~g} / \mathrm{L}$, $p<0.05)$. This increase of blood serum IgG concentration was also observed at 30 and 40 hours after delivery, but there were no statistically significant differences between the control and treated animals $(60 \pm 14: 52 \pm 8$ and $56 \pm 15: 47 \pm 9 \mathrm{~g} / \mathrm{L}$, $\mathrm{p}>0.05)$.

The blood serum patterns of NEAA and EAA in the control and calves orally treated with zeolite are presented in Tables 5-6.

Table 5. Blood serum ${ }^{\mathrm{a}}$ pool free NEAA concentrations ( $\left.\mu \mathrm{mol} / \mathrm{L}\right)$ from the control and treated group of calves

\begin{tabular}{|c|c|c|c|c|c|c|c|c|}
\hline \multirow{2}{*}{ NEAA } & \multicolumn{4}{|c|}{ CONTROL } & \multicolumn{4}{c|}{ TREATED } \\
\cline { 2 - 9 } & \multicolumn{1}{|c|}{$6^{\mathrm{h}}$} & $16^{\mathrm{h}}$ & \multicolumn{1}{c|}{$30^{\mathrm{h}}$} & \multicolumn{1}{c|}{$40^{\mathrm{h}}$} & $6^{\mathrm{h}}$ & $16^{\mathrm{h}}$ & $30^{\mathrm{h}}$ & $4^{\mathrm{h}}$ \\
\hline \hline Asp & 293.3 & 583.4 & 163.5 & 206.2 & 306.3 & 183.9 & 271.2 & 214.7 \\
\hline Glu & 240.8 & 421.3 & 284.1 & 187.6 & 344.5 & 477.4 & 358.7 & 384.9 \\
\hline Ser & 81.9 & 147.3 & 276.2 & 209.6 & 223.1 & 302.3 & 275.5 & 222.2 \\
\hline Gly & 177.8 & 439.3 & 447.5 & 489.1 & 665.4 & 758.6 & 493.5 & 552.6 \\
\hline Ala & 65.2 & 402.6 & 348.1 & 333.7 & 411.8 & 583.7 & 293.1 & 313.6 \\
\hline Pro & 40.5 & 314.5 & 239.5 & 232.4 & 392.5 & 466.4 & 355 & 342.5 \\
\hline Tyr & 12 & 43.1 & 67.2 & 24.5 & 61.3 & 81.4 & 45.4 & 36.1 \\
\hline TOTAL & 911.5 & 2351.5 & 1826.1 & 1683.1 & 2404.9 & 2853.7 & 2092.4 & 2066.6 \\
\hline
\end{tabular}

Legend: ${ }^{a}$ each number represents a value of free AA concentration in the pooled blood serum sample of 15 animals. 
Data presented in Table 5. indicate that total pooled blood serum free NEAA concentration was approximately 2.5 times higher in treated calves at 6 hours after delivery (911.5:2404.9 $\mu \mathrm{mol} / \mathrm{L}$; control vs. treated). During the later periods of investigation (16h, 30h and 40h) differences in the total pooled blood serum free NEAA concentrations between control and treated groups of calves were relatively smaller.

Total pooled blood serum free EAA concentrations in the control and treated calves are presented in Table 6.

Table 6. Blood serum ${ }^{\mathrm{a}}$ pool free EAA concentrations ( $\left.\mu \mathrm{mol} / \mathrm{L}\right)$ from the control and treated group of calves

\begin{tabular}{|l|c|r|r|r|r|r|r|r|}
\hline \multirow{2}{*}{ EAA } & \multicolumn{4}{|c|}{ CONTROL } & \multicolumn{4}{c|}{ TREATED } \\
\cline { 2 - 9 } & $6^{\mathrm{h}}$ & \multicolumn{1}{|c|}{$16^{\mathrm{h}}$} & \multicolumn{1}{c|}{$30^{\mathrm{h}}$} & \multicolumn{1}{c|}{$40^{\mathrm{h}}$} & $6^{\mathrm{h}}$ & \multicolumn{1}{c|}{$16^{\mathrm{h}}$} & \multicolumn{1}{c|}{$30^{\mathrm{h}}$} & \multicolumn{1}{c|}{$40^{\mathrm{h}}$} \\
\hline \hline His & 49.2 & 149.7 & 87.8 & 145.2 & 186.1 & 179.1 & 190.1 & 244.4 \\
\hline Thr & 54.9 & 170.3 & 197.4 & 218.8 & 134.1 & 225.6 & 215.6 & 175.5 \\
\hline Arg & 34 & 91.4 & 162.9 & 208.4 & 147.8 & 144.5 & 202.9 & 189.1 \\
\hline Val & 67.3 & 256.8 & 279.6 & 340.7 & 220.5 & 365.1 & 357.7 & 356.3 \\
\hline Met & 17.8 & 28.3 & 29.2 & 29.4 & 14.3 & 56.5 & 38.1 & 21.3 \\
\hline Ile & 20.9 & 72.8 & 79 & 87.1 & 87.2 & 94.3 & 110.1 & 76.3 \\
\hline Leu & 34.4 & 149.7 & 128.7 & 157.2 & 140.7 & 192.2 & 148.3 & 140.3 \\
\hline Phe & 40.3 & 100.1 & 105.5 & 85.7 & 102.5 & 126.1 & 80.6 & 74.6 \\
\hline \hline Total & 318.8 & 1019.1 & 1070.1 & 1272.5 & 1033.2 & 1383.4 & 1343.4 & 1277.8 \\
\hline
\end{tabular}

Legend: ${ }^{a}$ each number represents a value of free AA concentration in the pooled blood serum sample of 15 animals

The total pooled blood serum free EAA concentration was more than 3 times higher in the calves orally treated with zeolite at 6 hours after delivery (318.8:1033.2 $\mu \mathrm{mol} / \mathrm{L}$, control vs. treated). Similar, but smaller tendency was also evident in the next two periods of investigation (16h and 30h), with the pooled blood serum free EAA values almost equal at the end of investigation (1272.5:1277.8 $\mu \mathrm{mol} / \mathrm{L}$; control vs. treated, at 40h after delivery).

Relative differences in the pooled blood serum free AA concentrations are presented in Figures 4-7.

The data presented in Figures 4-7 indicate that oral zeolite treatment in newborn calves on colostral diet induced an increase of: 1) blood serum free polar and positive AA (between $250-300 \%$ at 6 h after delivery), 2) blood serum free polar and neutral AA (between 150-200\% for Ser and Thr; more than 400\% for Tyr, at 6 hours after delivery), and 3 ) blood serum free nonpolar and neutral AA, except Met (between $150-850 \%$ at $6 \mathrm{~h}$ after delivery). A smaller increase of the same categories of total pooled blood serum free $A A$ was evident at $16 \mathrm{~h}$, with gradual balance reaching at the latter time intervals (30h and $40 \mathrm{~h})$. The oral zeolite 
treatment had minimal effect on polar and negative blood serum free AA relative concentration (Asp and Glu).

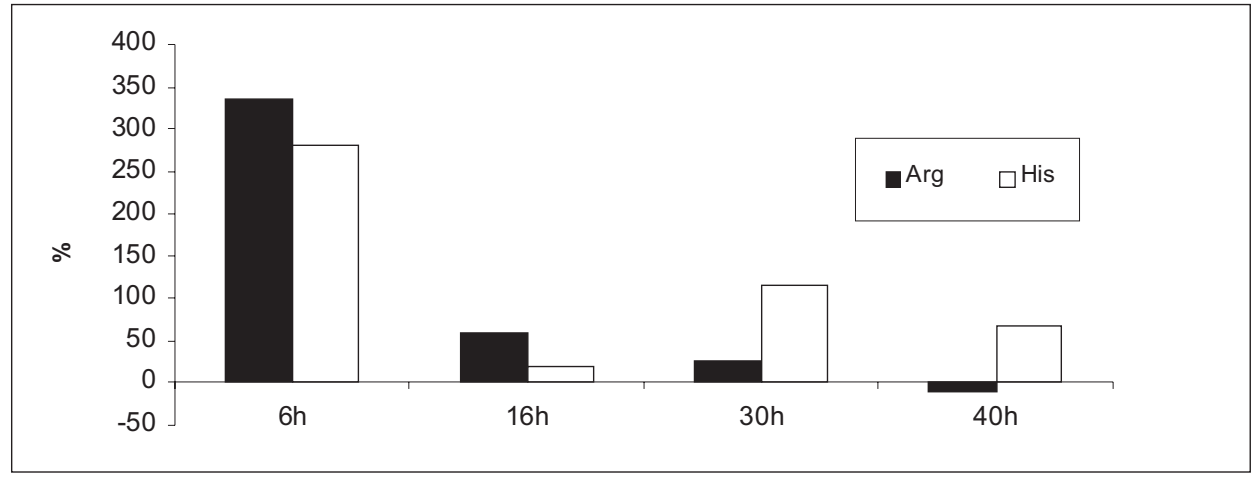

Figure 4. Polar and positive blood serum free amino acid pattern in the control and calves orally treated with zeolite (difference in \% between pools)

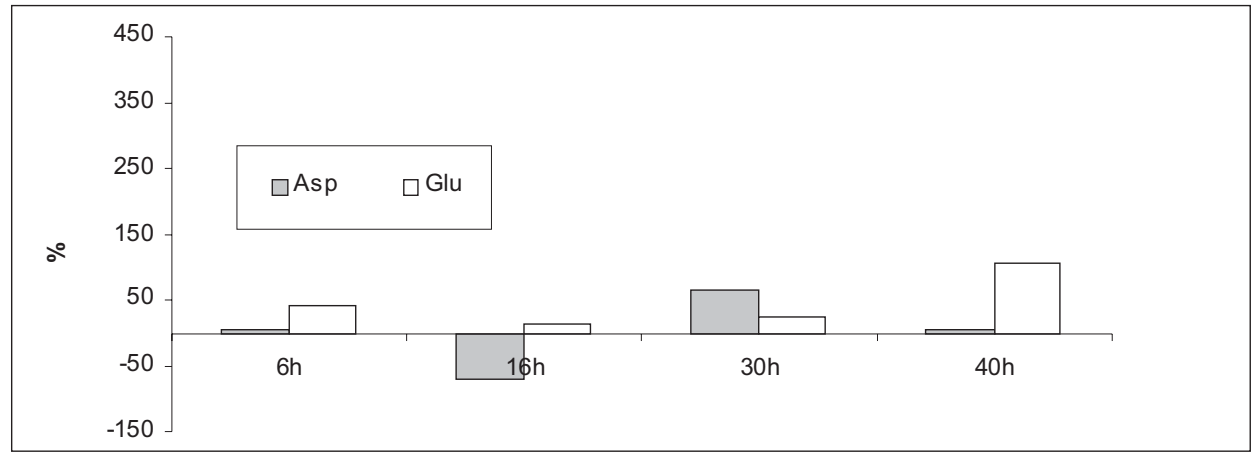

Figure 5. Polar and negative blood serum free amino acids pattern in the control and calves orally treated with zeolite (difference in \% between pools)

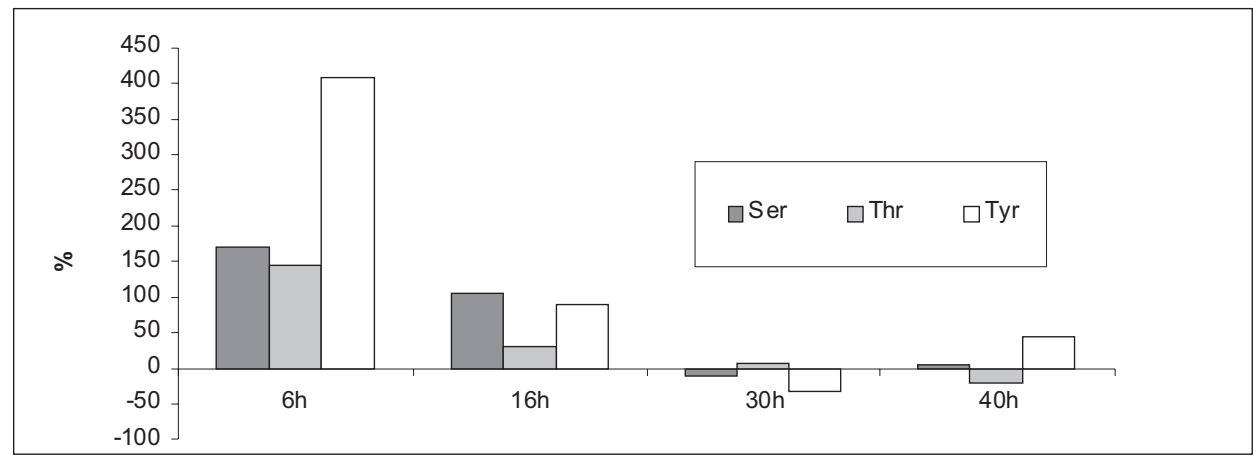

Figure 6. Polar and neutral blood serum free amino acid pattern in the control and calves orally treated with zeolite (difference in \% between pools) 


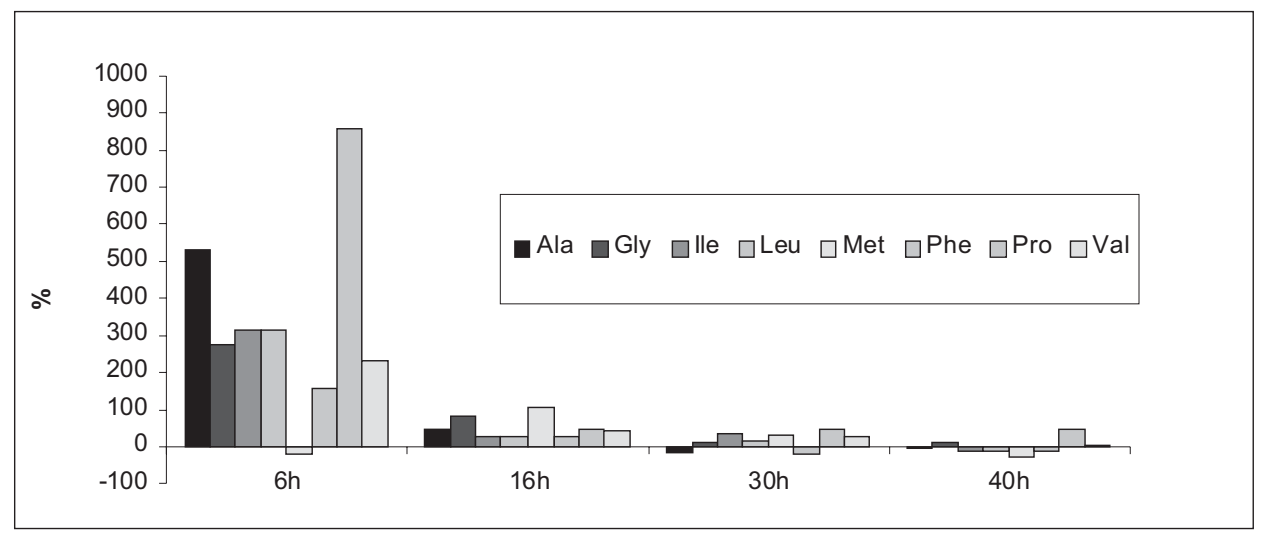

Figure 7. Nonpolar and neutral blood serum free amino acid pattern in the control and calves orally treated with zeolite (difference in \% between pools)

\section{DISCUSSION}

Colostrum is the specific first diet of mammalian neonates. The dry matter in colostrum consists of protein, peptides, peptide and nonpeptide hormones, cytokines, enzymes, poliamines and nucleotides, carbohydrates (mainly lactose), fats, minerals and vitamins (Oyeniyi et al., 1978; Koldovsky, 1989; Grosvenor et al., 1993). Total colostral protein and whey protein concentrations decline significantly between the first and second milking. Our results of total colostral protein and colostral whey protein concentrations were similar to those reported by Oyeniyi et al. (1978) and Hadorn et al. (1997).

Colostral antibodies in neonatal calves are essential in providing temporary passive immunity. The principal immunoglobulin in bovine colostrum is IgG (Butler, 1974). Our previous results indicate that oral zeolite treatment in newborn calves significantly increases IgG resorption (Stojić et al., 1995; 1998), that has also been confirmed in this study. Calculation of the apparent efficiency of immunoglobulin absorption (AEA\%, Qugley et al., 1998) in newborn calves orally treated with zeolite indicates a significant positive effect of this treatment (Gvozdić et al., 2008).

Major factors influencing total plasma free amino acids concentration are: 1) protein synthesis, 2) protein degradation, 3) tissue uptake and efflux, 4) influx from the small intestine, and 5) amino acid catabolism (Bergen, 1979). The body free AA pool represents only about 2-3\% of the protein bound AA in the body (Herbert et al., 1966). Furthemore, free AA in blood plasma (or serum) represent a small proportion (only about 2\%) of the total body free AA pool (Herbert et al., 1966; Johns et al., 1976). Despite this plasma free AA profiles are often determined to asses the protein and $A A$ nutritional status of animals.

Bovine colostrum (first milking) has a relatively small amount of free nonessential and essential amino acids (105 $\mu \mathrm{mol} / \mathrm{L}$ of total NEAA; $429.2 \mu \mathrm{mol} / \mathrm{L}$ of total EAA). At the same time protein-bound amino acid composition was 
$369749 \mu \mathrm{mol} / \mathrm{L}$ of the total EAA and $455272 \mu \mathrm{mol} / \mathrm{L}$ of the total NEAA (Zanker et al., 2000). Studies in milk fed calves have shown that the plasma level of AA administered as free AA increases after less than 2 hours from ingestion, whereas protein-bound AA appear in the blood much later (Vacher et al., 1990). First colostrum feeding in our experimental animals was between 0-2 hours after delivery and blood serum free NEAA and EAA level increases more than twice in the treated calves at 6 hours after delivery. Since bovine colostrum contains low amounts of free AA (Zanker et al., 2000), most of the blood serum free AA at 6 hours after delivery probably originates from the intestinal colostral protein digestion. Our results indicate that total pooled blood serum free NEAA and EAA concentration is increased (Table 5 and 6) 4 hours after the first colostrum intake, representing oral zeolite treatment effects in newborn calves. We assume a minor influence of zeolite on adsorption of free AA in the intestinal content because in vitro experiments using chemisorption index showed that zeolite has no adsoprtion effect on triptophan (Trp) and phenilalanine (Phe) (Tomašević-Čanović et al., 1996). This assumption leads to other possible explanations of zeolite effects, such as: 1) an increase of colostral protein digestion, and/or 2) an enhancement of the intestinal free AA absorption. Based on functional studies in the kidney and intestines five AA transport systems were proposed (Bröer, 2008): 1) the "neutral system" or "methionine preferring system" transporting all neutral amino acids; 2) the "basic system" transporting cationic amino acids together with cystine; 3) the "acidic system" transporting glutamate and aspartate; 4) the "iminoglycine system" transporting proline, hydroxyproline, and glycine; and 5) the $\beta$-amino acid system. It seems that among these systems in newborn calves on colostral diet only the "acidic system" transporting glutamate and aspartate has not been influenced by the oral zeolite treatment at 6 hours after delivery. Among nonpolar and neutral pooled blood serum free AA only Met relative difference is negative at 6 hours after delivery (Figure 7). Zanker et al. (2000) has reported $13486 \mu \mathrm{mol} / \mathrm{L}$ of protein-bond and $6 \mu \mathrm{mol} / \mathrm{L}$ of free Met in the first milking, and blood plasma free Met concentration of $54.5 \pm 10.3 \mu \mathrm{mol} / \mathrm{L}$ (12 hours after colostrum intake). Our results were almost the same for the treated animals in the same time relative to the colostrum intake $(56.5 \mu \mathrm{mol} / \mathrm{L}, 16 \mathrm{~h})$, but much lower at 6 hours after birth (17.8 and $14.3 \mu \mathrm{mol} / \mathrm{L}$, control and treated, respectively). The intestinal Met absorption may be reduced because of other free AA using the same transport system.

The results of our previous studies on the oral zeolite treatment in newborn animals (Stojić et al., 1995, 1998; Gvozdić et al., 2008) led us to the conclusion that a mineral adsorbent could bind some degradation products of colostral proteins in the intestine (ammonia, for example), thus preventing their negative effect on the intestinal epithelial cells. This may affect both - colostral protein digestion, as well as intestinal free AA absorption, thus increasing blood serum free AA concentration in newborn animals.

ACKNOWLEDGEMENTS:

The Ministry of Science and Technology, Republic of Serbia, Project Grant No. 143022 supported this research. 
Address for correspondence:

Dr Dragan Gvozdić

Department of Pathophysiology

Faculty of Veterinary Medicine

University of Belgrade

Bul. oslobođenja 18

11000 Belgrade, Serbia

E-mail: gvozdic@vet.bg.ac.rs

\section{REFERENCES}

1. Bergen WG, 1979, Free amino acids in blood of ruminants - physiological and nutritional regulation, J Anim Sci, 49, 6, 1577-89.

2. Bröer S, 2008, Amino acid transport across mammalian intestinal and renal epithelia, Physiol Rev, 88, 249-86.

3. Butler JE, 1974, Immunoglobulins in the mammary secretions. In: Lactation (Larson BL \& Smith VR, eds.), 3, 217256, Academic Press, New York, NY.

4. Caebello G, Levieux D, 1980, Comparative absorption of colostral lgG1 and IgM in the newborn calf. Effects of thyroxine, cortisol and environmental factors, Ann Rech Vet, 11, 1, 1-7.

5. Daković A, Matijašević S, Rottinghaus GE, Dondur V, Pietrass T, Clewett FM, 2007, Adsorption of zearalenone by organomodified natural zeolitic tuff, J Colloid Interface Sci, 311, 8-13.

6. Grosvenor CE, Picciano MF, Baumrucker CR, 1993, Hormones and growth factors in milk, Endocrine Rev, 14, 710-28.

7. Guilloteau P, Corring T, Garnot P, Martin P, Toullec R, Durand D, 1983, Effect of age and weaning on enzyme activities of abomasum and pancreas of the lamb, J Dairy Sci, 66, 2373-85.

8. Gvozdić D, Stojić V, Šamanc H, Fratrić Natalija, Daković Aleksandra, 2008, Apparent efficiency of immunoglobilin absorption in newborn calves orally treated with zeolite, Acta Veterinaria (Beograd), 58, 4, 345-55.

9. Hadorn U, Hammon H, Bruckmaier MR, BlumWJ, 1997, Delaying colostrum intake by one day has important effects on metabolic traits and on gastrointestinal and metabolic hormones in neonatal calves, J Nutr 127, 2011-23.

10. Herbert JD, Coulson RA, Hernandez T, 1966, Free amino acids in the caiman and rat, Comp Biochem Physiol, 17, 583.

11. Jensen PT, 1978, Trypsin inhibitor in sow colostrum and its function, Ann Rech Vet, 9, 225-8.

12. Johns JT, Bergen WG, 1976, Growth in sheep, pre- and postweaning hormone changes and muscle and liver development, J Anim Sci, 41, 1757.

13. Koldovsky $O, 1989$, Search for a role of milk-borne biologically active peptides for the suckling, $J$ Nutr, 119, 1543-51.

14. Kruse PE, 1983, The importance of colostral immunoglobulins and their absorption from the intestine of the newborn animals, Ann Rech Vet, 14, 4, 349-53.

15. Mihajlović-Radosavljević A, Daković A, Lemić J, Matijašević S, Tomašević-Čanović M, 2003, Physical chemical properties and acid stability of zeolitic tuff. In Kuzev L, Nishkov I, Boteva A, Mochev D (Eds.), Mineral Processing in the 21st Century, Proceedings of the X Balkan Mineral Processing Congress, Varna, Bulgaria, 15-20 July 2003, 897-902.

16. Mumpton FA, 1998, Development of uses for natural zeolites: a critical commentary. In: Kallo D, and Sherry HS (Eds), Occurence, Properties and Utilization of Natural Zeolites, Akademia Kiado, Budapest, 333.

17. Oyeniyi OO, Hunter AG, 1978, Colostral constituens including immunoglobulins in the first three milkings postpartum, J Dairy Sci, 61, 1, 44-8.

18. Pallavicini C, Ciruzzi B, Laudadio V, 1984, Isolamento e parziale caratterizzazione del'inhibitore della tripsina del colostro ovino, Latte, 9, 309-12. 
19. Patureau Mirand P, Bernard O, Prugnaud J, Arnal M, 1985, Métabolisme protéique de l'agneau nouveau-né. II. Influence de l'alimentation sur les flux et le taux de renouvellement des protéines, Reprod Nutr Dev, 25, 1061-73.

20. Patureau Mirand P, Houlier ML, Prugnaud J, Dalle M, Grizard J, 1990, Métabolisme protéique de l'agneau nouveau-né. IV. Conséquences de l'ingestion d'acides aminés et de lactose, Reprod Nutr Dev, 30, 203-14.

21. Quigley III JD, Drewry JJ, 1998, Nutrient and immunity transfer from cow to calf pre- and postcalving, J Dairy Sci, 81, 2779-90.

22. Stojić V, Gagrčin M, Kirovski Danijela Fratrić Natalija, 1998. The effect of clinoptilolite based mineral adsorber immunoglobulin G absorption in newborn piglets, Acta Veterinaria (Beograd), 48, 1926.

23. Stojić V, Šamanc H, Fratrić Natalija, 1995, The effect of a clinoptilolite based mineral adsorber on colostral immunoglobulin G adsorption in newborn calves, Acta Veterinaria (Beograd), 45, 2-3, 67-74.

24. Stott $\mathrm{GH}$, Fellah A, 1983, Colostral immunoglobulin absorption linearly related to concentration for calves, J Dairy Sci, 66, 6, 1319-28.

25. Stott GH, Marx DB, Menefee BE, Nightengale GT, 1979a, Colostral immunoglobulin transfer in calves II. The rate of absorption, J Dairy Sci, 62, 1766-73.

26. Stott GH, Marx DB, Menefee BE, Nightengale GT, 1979b, Colostral immunoglobulin transfer in calves III. Amount of absorption, J Dairy Sci, 62, 1902-7.

27. Stott GH, Marx DB, Menefee BE, Nightengale GT, 1979c, Colostral immunoglobulin transfer in calves IV. Effect of suckling, J Dairy Sci, 62, 1908-13.

28. Tomašević-Ćanović Magdalena, Dumić M, Vukićević Olivera, 1996, The adsorption effects of mineral adsorber on the clinoptilolite basis. II. Adsorption behavior in the presence of aminoacids and vitamins, Acta Veterinaria (Beograd), 46, 4, 227-34.

29. Vacher PY, Schmitz M, Hirni H, Blum JW, 1990, Postprandial plasma variations of 3-methylhistidine compared to those of lysine, homoarginine and xylose on the normal conditions and in malabsorption in the suckling calf. Reprod Nutr Dev, 30, 4, 471-82.

30. Ward RL, McKague HL, 1994, Clinoptilolite and heulandite structural differences as revealed by multinuclear nuclear magnetic resonance spectroscopy, J Phys Chem, 98, 1232-37.

31. Zanker Al, Hammon HM, Blum JW, 2000, Plasma amino acid pattern during the first month of life in calves fed the first colostrum at 0-2h or at 24-25h after birth, $J$ Vet Med, A, 46, 107-21.

\title{
SLOBODNE AMINOKISELINE U KRVNOM SERUMU KOD NOVOROĐENE TELADI ORALNO TRETIRANE ZEOLITOM U PERIODU KOLOSTRALNE ISHRANE
}

\author{
GVOZDIĆ D, ALEKSIĆ JELENA, FRATRIĆ NATALIJA, JAKIĆ-DIMIĆ DOBILA, STOJIĆ V, \\ PAVLOVIĆ V, PAVLOVIĆ M I VAKANJAC SLOBODANKA
}

\section{SADRŽAJ}

$\mathrm{U}$ ovom radu su izneti rezultati ispitivanja uticaja oralnog tretmana zeolitom na koncentraciju slobodnih aminokiselina u krvnom serumu kod novorođene teladi. Ispitivanje je izvršeno na ukupno 30 novorođenih teladi, oba pola, prosečne telesne mase $35 \pm 3 \mathrm{~kg}$ (srednja vrednost $\pm S D$ ), koja su neposredno nakon partusa odvojena od majke i smeštena u individualne bokseve. Telad su podeljena u dve ogledne grupe sa po 15 životinja u svakoj grupi. Sva telad su hranjena dva 
puta dnevno (1.5 L/obroku) u toku prvih 48 sati nakon partusa kolostrumom njihovih majki, u intervalu od 12 sati, počevši od 2 sata nakon partusa. U toku prva 24 sata telad su hranjena prvim kolostrumom (skupljen u toku prvih 24 sata) dok su u sledeća 24 sata hranjena drugim kolostrumom (skupljen u periodu od 24-48 sati nakon partusa). Tretirana grupa teladi dobijala je sa svakim obrokom suspenziju zeolita (20 mL, 25\% suspenzije zeolita u destilovanoj vodi).

Uzorci kolostruma uzimani su od 6 krava u periodu od 0 - 12 sati i 24 sata nakon partusa i kolorimetrijskom metodom je određivana koncentracija proteina u kolostrumu i kolostralnom mlečnom serumu. Uzorci krvi od teladi uzimani su iz v. jugularis $6,16,30$. i 40 . sata nakon partusa, nakon spontane koagulacije na sobnoj temperaturi je odvajan krvni serum i čuvan na $-20^{\circ} \mathrm{C}$ do momenta analize. Koncentracija ukupnih proteina u uzorcima krvnog seruma teladi je određivana kolorimetrijskom metodom, a koncentracija imunoglobulina $\mathrm{G}$ (IgG) radioimunodifuzionim testom (sRID). Koncentracija slobodnih aminokiselina je određivana u zbirnim uzorcima krvnog seruma (aspartat - Asp, glutamat - Glu, serin - Ser, histidin - His, glicin - Gly, treonin - Thr, alanin - Ala, prolin - Pro, tirozin - Tyr, arginin Arg, valin - Val, metionin - Met, leucin - Leu, izoleucin - Ile, fenilalanin - Phe) metodom visoko precizne tečne hromatografije (HPLC, GBC Australia).

Koncentracija ukupnih proteina u kolostrumu i kolostralnom mlečnom serumu je bila statistički značajno viša u prvom kolostrumu i snižena je između 50$75 \%$ u periodu 24-48 sati nakon partusa. Srednje vrednosti koncentracije IgG u krvnom serumu 6. i 16. sata nakon partusa bile su statistički značajno više kod tretirane grupe teladi u odnosu na kontrolnu grupu životinja (26 $\pm 7: 20 \pm 5$ i 55 \pm 15 : $42 \pm 13 \mathrm{~g} / \mathrm{L}, \mathrm{p}<0.05)$. Koncentracija ispitivanih slobodnih neesencijalnih i esencijalnih aminokiselina u zbirnim uzorcima krvnog seruma je povišena u svim vremenskim intervalima kod tretirane grupe teladi. Najveći stepen porasta koncentracije zabeležen je kod polarnih pozitivnih (Arg, His), polarnih neutralnih (Ser, Thr, Tyr) i nepolarnih neutralnih slobodnih aminokiselina (izuzev Met). Minimalni efekat oralnog tretmana zeolitom zabeležen je u slučaju koncentracije polarnih negativnih slobodnih aminokiselina (Asp i Glu) u zbirnim uzorcima krvnog seruma tretirane grupe teladi. 